\title{
Rancang Bangun Aplikasi Text Mining dalam Mengelompokkan Judul Penelitian Dosen Menggunakan Metode Shared Nearest Neighbor dan Euclidean Similarity
}

\author{
Lisna Zahrotun, Mushlihudin \\ Program Studi Teknik Informatika, Fakultas Teknologi Industri, Universitas Ahmad Dahlan \\ Kampus3, Jln. Prof. Dr. Supomo, Janturan, Yogyakarta 55164 \\ e-mail: lisna.zahrotun@tif.uad.ac.id
}

\begin{abstract}
Data mining is the process of extracting hidden information into a know ledge. Some types of data in data mining are web mining, text mining, sequence mining, graph mining, temporal data mining, spatial data mining, distributed data mining and multimedia mining. Document grouping is one of the techniques of text mining. The purpose of this research is to build the application of lecturer research title classification using Shared nearest Neighbor method. The method used in the research is one of the methods of grouping in text mining that is Shared Nearest Neighbor (SNN) with Euclidean Similarity. Testing is done using black box test. The result of this research is text mining application that able to clustering the title of research lecturer.
\end{abstract}

Keywords: text mining; shared nearest neighbor; euclidean similarity

\begin{abstract}
Abstrak
Data mining adalah proses untuk mengekstrak informasi tersembunyi menjadi sebuah pengetahuan. Beberapa jenis data dalam data mining adalah web mining, text mining, sequence mining, graph mining, temporal data mining, mining spatial data, Mining data terdistribusi dan multimedia mining. Pengelompokan dokumen merupakan salah satu teknik dari text mining. Tujuan penelitian ini adalah untuk membangun aplikasi pengelompokkan judul penelitian dosen menggunakan metode shared nearest neighbor. Metode yang digunakan dalam penelitian merupakan salah satu metode pengelompokkan dalam text mining yaitu shared nearest neighbor (SNN) dengan euclidean similarity. Pengujian dilakukan menggunakan black box test. Hasil dari penelitian ini adalah aplikasi text mining yang mampu mengelompokkan judul penelitian dosen.
\end{abstract}

Kata kunci: text mining; shared nearest neighbor; euclidean similarity

\section{Pendahuluan}

Data mining adalah proses untuk mengekstrak informasi tersembunyi menjadi sebuah pengetahuan. Beberapa jenis data dalam data mining adalah web mining, text mining, sequence mining, graph mining, temporal data mining, mining spatial data, Mining data terdistribusi dan multimedia mining [1]. Text mining merupakan proses penggalian data tersembunyi dengan data berbentuk text. Salah satu teknik dalam text mining adalah pengelompokkan. Pengelompokkan merupakan teknik yan digunakan untuk membentuk kelompok-kelompok yang memiliki kemiripan atau kesamaan dalam data dalam setiap kelompoknya [2]. Ini berarti satu objek memiliki kemiripan dalam setiap kelompok dan ketidak miripan terhadap objek pada kelompok lain. Metode shared nearest neighbor (SNN) merupakan metode pengelompokkan yang baik, dimana dalam metode ini pengelompokkan ditentukan dengan mencari ketetanggaan terdekat dari semua titik yang telah ditentukan sebelumnya [3]. Beberapa penelitian tentang text mining diantaranya penelitian yag membandingkan cosine similarity dan jaccard similarity pada metode SNN[4]. Perancangan aplikasi pengelompokkan 
Jurnal IImu Teknik Elektro Komputer dan Informatika (JITEKI)

Vol. 3, No. 2, Desember 2017

judul penelitian dosen meggunakan metode SNN juga pernah dilakukan, dimana dalam penelitian ini dihasilkan desaign aplikasi text mining [5]. Penggunaan metode K-Nearest Neigbour (KNN) untuk kategorisasi teks [6], pengelompokan teks data dengan fuzzy c-means [7], pengelompokkan dengan AHC single linked dan K-Means [8], dan text mining pengelompokkan judul kerja praktek dengan menggunakan metode K-Means yang dikolaborisakan dengan metode AHC untuk menentukan titik pusat awalnya [9].

Dengan banyaknya penelitian dan skema-skema dari penelitian maka tentunya penelitian yang dihasilkan juga akan sangat beragam dan bervariasi. Salah satu kendala dosen dalam penelitian adalah mencari pasangan yang tepat yang sesuai dengan bidang keilmuan. Padahal bidang keilmuan ini dapat dilakukan dengan dosen antar program studi. Jika para dosen mengetahui bidang minat dan riwayat dari penelitian-penelitian sebelumnya dosen lain tentu ini akan memudahkan dosen dalam berkolaborasi dengan dosen lain untuk melakukan penelitian.

Dengan demikian, dengan melihat dari penelitian-penelitian sebelumnya dan agar juduljudul penelitian dosen dari UAD dapat bermanfaat maka dilakukan penelitian dengan judul "Rancang Bangun Aplikasi Text Mining dalam Mengelompokkan Judul Penelitian Dosen Menggunakan Metode Shared Nearest Neighbor dan Euclidean Similarity'. Dalam penelitian ini dilakukan pengembangan dari penelitian sebelumnya yaitu perancangan text mining pengelompokkan judul penelitian dosen menjadi sebuah aplikasi berbasis web yang mampu mengelompokkan judul penelitian dosen.

\section{Metode Penelitian}

Metode penelitian yangg dilakukan adalah pengumpulan data, analisis sistem, perancangan, implementasi dan pengujian. Pengumpulan data dilakukan dengan studi literatur dari berbagai macam buku, artikel, publikasi ilmiah untuk mempelajari mekanisme teks Mining dalam mengelompokkan data, mekanisme pengelompokan data menggunakan metode SNN dan algoritma SNN dan euclidean similarity. Selain itu juga dilakukan wawancara dengan cara bertanya langsung terhadap nara sumber yaitu kepada karyawan yang menangani tentang pendataan penelitian dosen UAD. Metode observasi juga dilakukan dengan cara melihat proses pendataan judul penelitian dosen melalui website Ipp.uad.ac.id dan juga pendataan judul penelitian dosen menggunakan form hardcopy.

Analisis sistem dilakukan dengan beberpa tahap dalam yang mengcu pada prose text mining yaitu cleaning, tokenizing, filtering. Kemudian penghitungan similarity menggunakan Euclidean similarity dan pemahaman dari algoritma shared nearest neighbor (SNN). Algoritma shared nearest neighbor (SNN) merupakan proses pengelompokkan pada data yang memiliki dimensi tinggi yang telah dikembangkan [3]. Algoritma SNN memerlukan 3 masukan parameter yaitu $k$ yang merupakan jumlah tetangga terdekat, $e$ yang merupakan nilai ambang ketetanggaan yang dimiliki secara bersama dan mint yang merupakan jumlah minimal data untuk setiap kelompok.

Langkah-langkah Algoritma shared nearest neighbor (SNN)

a) Menghitung nilai kesamaan dari data yang ada

b) Membentuk daftar k-tetangga terdekat masing-masing titik data untuk $k$ data

c) Membentuk graph ketetanggaan dari daftar $k$ tetangga terdekat

d) Mencari kepadatan untuk setiap data

e) Menemukan titik-titik representatif

f) Membentuk kelompok dari titik-titik representatif tersebut

Sedangkan untuk menghitung jarak kemiripan antar judul digunakan euclidean similarity.

Euclidean similarity merupakan penentuan akar perbedaan persegi antara koordinat sepasang objek. Untuk jarak vektor $\mathrm{x}$ dan $\mathrm{y}(\mathrm{x}, \mathrm{y})$ ditunjukkan dalam persamaan 1 [10]

$$
\operatorname{Sim}(\mathrm{x}, \mathrm{y})=d=\sqrt{\sum_{i=1}^{n}\left(x_{i}-y_{i}\right)^{2}}
$$

Dimana $\mathrm{x}$ dan $\mathrm{y}$ adalah vektor $\mathrm{n}$-dimensi

Rancang Bangun Aplikasi Text Mining dalam Mengelompokan Judul Penelitian Dosen Menggunakan Metode Shared Nearest Neighbor dan Eucludien Similarity (L. Zahrotun) 
Jurnal IImu Teknik Elektro Komputer dan Informatika (JITEKI)

Vol. 3, No. 2, Desember 2017

Setelah melalui tahap analisis maka dilakukan prose peracangan. Tahap perancangan dilakukan untuk menurunkan hasil analisis ke tahap yang lebih detail. Beberapa tahap perancangan yang dilakukan adalah perancangan flowchart, perancangan basis data dan perancangan user interface. Perancangan flowchart meliputi tahapan text mining yang meliputi proses cleaning, tokenizing dan filtering. Dalam proses cleaning dilakukan pemotongan kata pada judul kerja praktek yang melebihi 12 kata. Sehingga dari data awal dalam data base jika ditemukan judul yang memiliki lebih dari 12 kata, maka kata ke 13 sampai terakhir dihilangkan. Tampilan flowchart proses cleaning ditunjukkan dalam Gambar 1. Proses tokenizing dalam penelitian ini di mulai dengan pengambilan data judul kerja praktek dalam data base, dari data judul kerja praktek tersebut kemudian dilakukan proses tokenizing. Hasil dari proses tokenizing ini disimpan dalam data base kembali. Flowchart proses tokenizing ditunjukkan dalam Gambar 2. Dalam penelitian ini proses filtering dilakukan dengan menggunakan modle stoplist atau membuang kata-kata yang tidak penting. Pertama kata-kata yang dianggap tidak penting di simpan dalam data base yaitu di, ke, dari, dan, untuk, pada, atau. Setelah di simpan dalam data base maka kaa yang tidak penting tersebut akan di panggil untuk dicocokkan terhadap kata pada setiap judul. Jika ditemukan salah satu dari daftar stoplist di dalam judul kerja praktek maka kata tersebut akan dihapus oleh system. Hasil proses filtering ini kemudian disimpan dalam data base. Flowchart proses filering ditampilkan dalam Gambar 3.

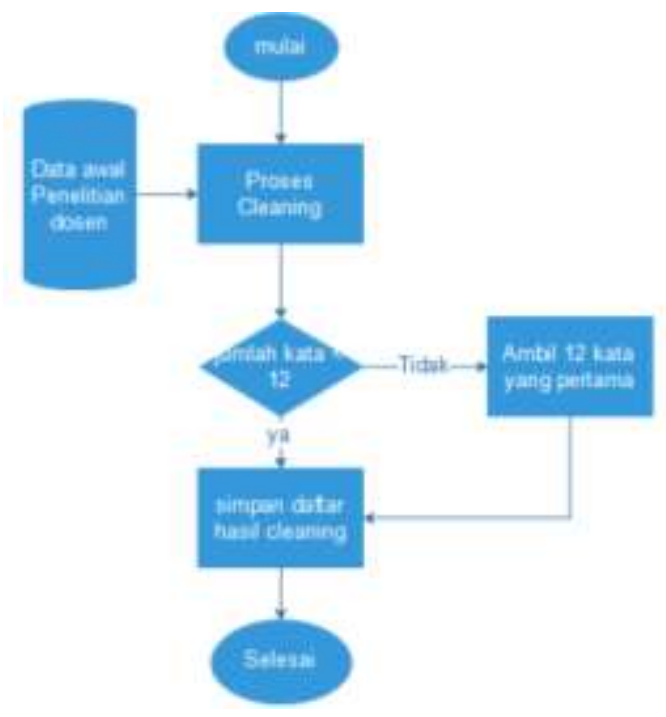

Gambar 1. Flowchart proses cleaning

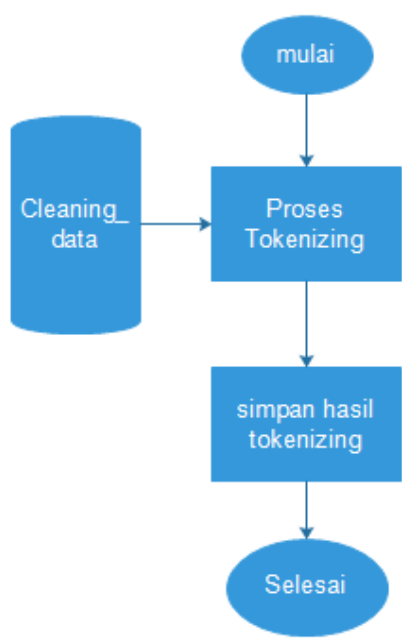

Gambar 2. Flowchart proses tokenizing 


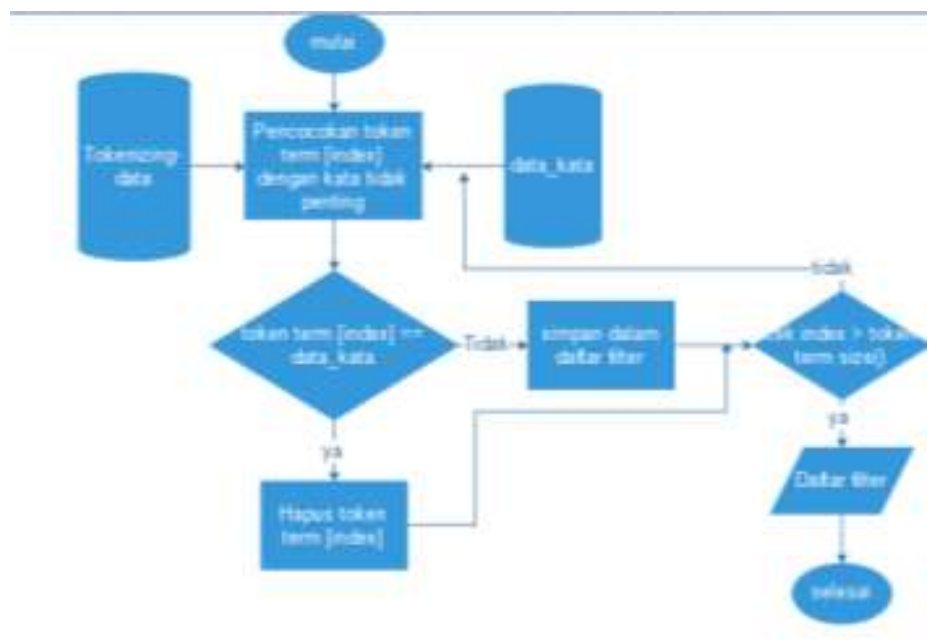

Gambar 3. Flowchart proses filtering

Perancangan basis data meliputi tabel data kata untuk menyimpan setiap kata hasil dari tokenizing dan filtering untuk setiap judul, tabel data frekuensi untuk menyimpan frekuensi kemunculan setiap kata, tabel data nilai, untuk menyimpan nilai kemiripan setiap judul kerja praktek dengan judul kerja praktek yang lain dan tabel data cluster, untuk menyimpan judul yang yang telah dikelompokkan. Rancangan basis data digambarkan dalam bentuk ERD (entity relationship diagram) yang digunakan untuk pemodelan bisnis data relational. Gambar 4 menggambarkan tenatang rancangan basis data sistem dalam bentuk ERD. Tahap yang terakhir adalah impelentasi program dan pengujian

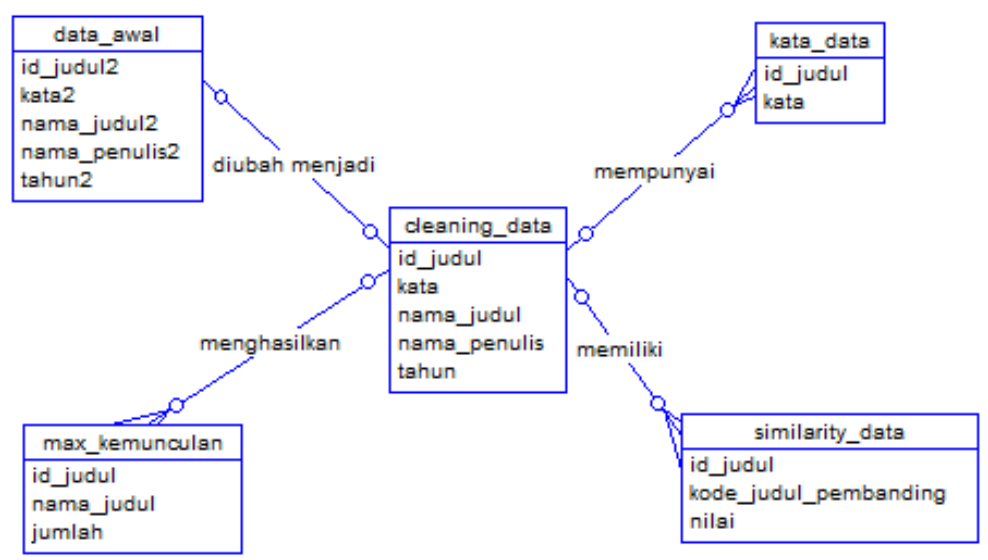

Gambar 4. Entity relationship diagram (ERD)

\section{Hasil dan Pembahasan}

Hasil dari penelitian ini adalah sebuah aplikasi pengelompokkan judul penelitian dosen, dengan sampel data yag digunakan adalah sejumlah 13 data. Aplikasi yang dibuat Dalam proses ini sistem mampu mengambil data dari excel. Tipe data yang dapat diakses oleh sistem ini adalah xls. Tampilan hasil proses load data ditunjukkan dalam Gambar 5. 
Jurnal IImu Teknik Elektro Komputer dan Informatika (JITEKI)

Vol. 3, No. 2, Desember 2017

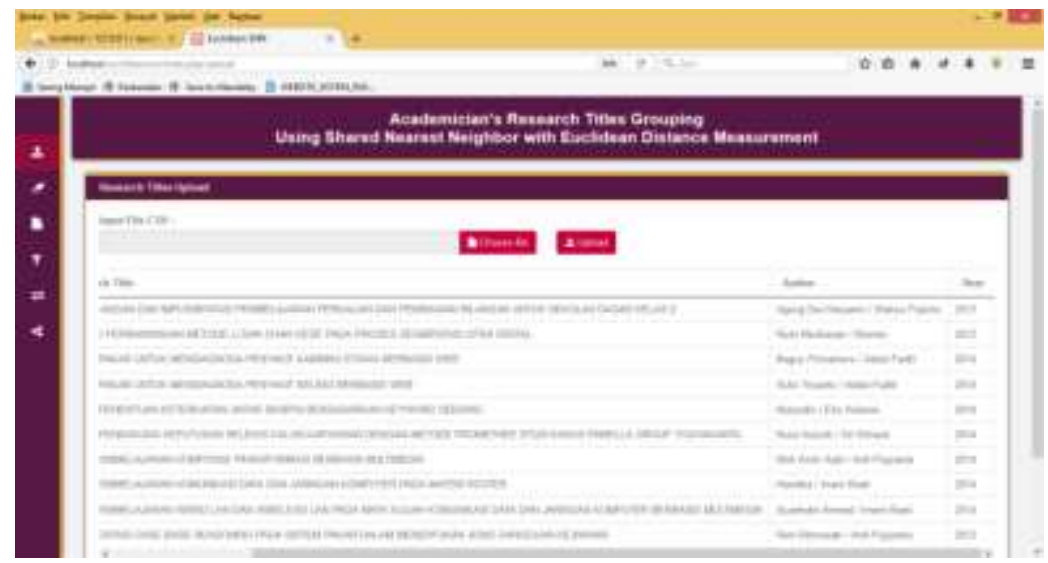

Gambar 5. Tampilan hasil proses load data

\subsection{Proses cleaning} Gambar 6.

Proses cleaning atau pembersihan data dalam aplikasi text mining ditunjukkan dalam

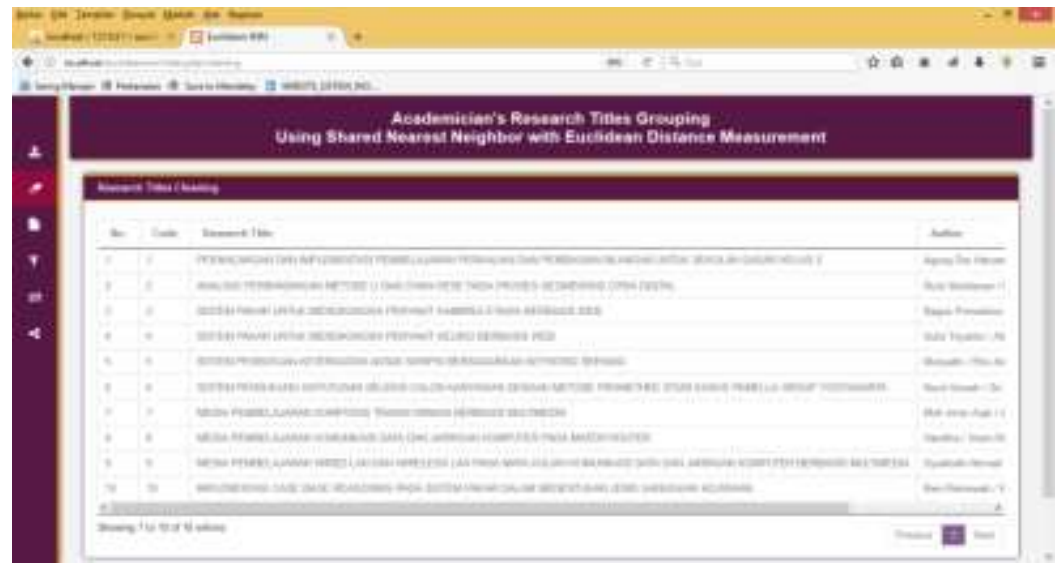

Gambar 6. Tampilan proses hasil cleaning

\subsection{Proses tokenizing}

Proses tokenizing data dalam aplikasi text mining ditunjukkan dalam Gambar 7.

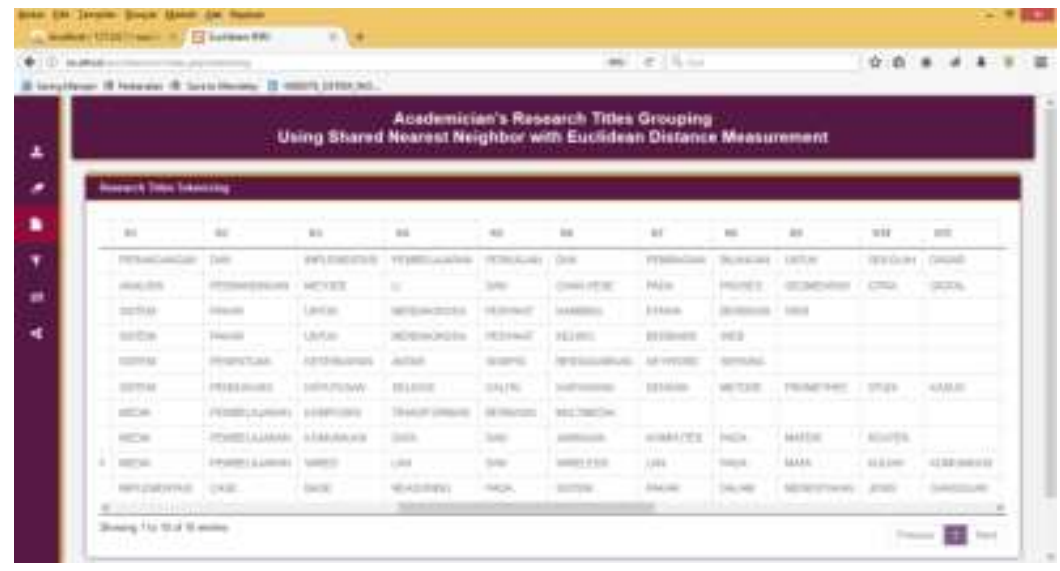

Gambar 7. Tampilan hasil proses tokenizing 
Jurnal IImu Teknik Elektro Komputer dan Informatika (JITEKI)

Vol. 3, No. 2, Desember 2017

\subsection{Tampilan filtering}

Tampilan daftar kata dalam aplikasi text mining ditunjukkan dalam Gambar 8.

\subsection{Proses penghitungan similarity} Gambar 9

Proses penghitungan similarity data dalam aplikasi text mining ditunjukkan dalam

\subsection{Proses pengelompokkan menggunakan metode SNN}

Proses pengelompokkan menggunakan metode SNN dalam aplikasi text mining. Tampilan hasil pengelompokkan direpresentasikan dalam dua bentuk yaitu daftar judul setiap kelompok yang ditunjukkan dalam Gambar 10 dan hasil pengelompokkan dalam bentuk grafik yang ditunjukkan dalam Gambar 11.

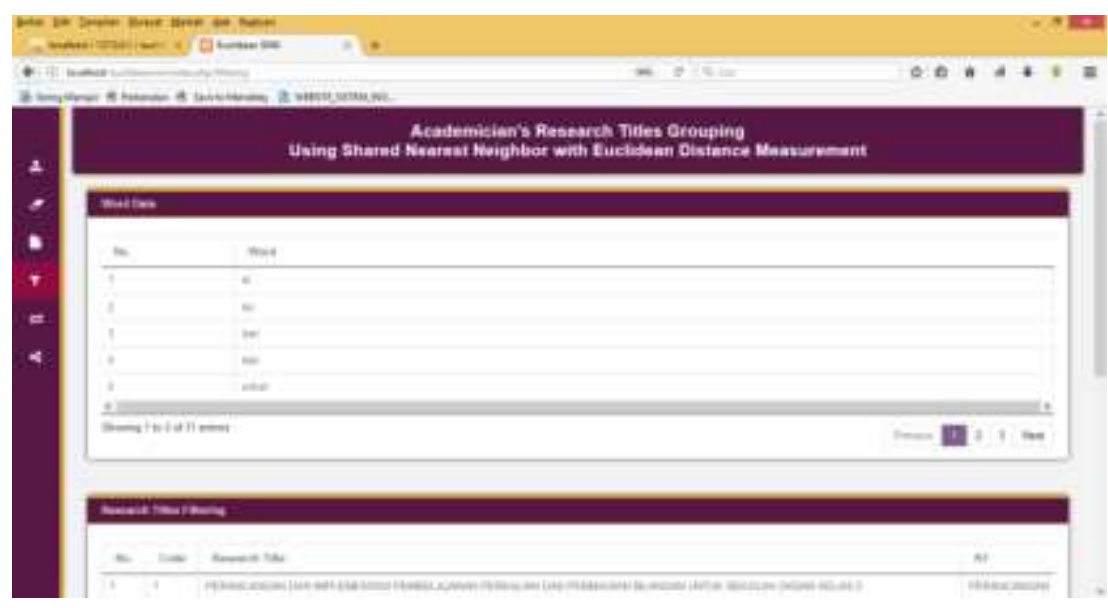

Gambar 8. Tampilan filtering

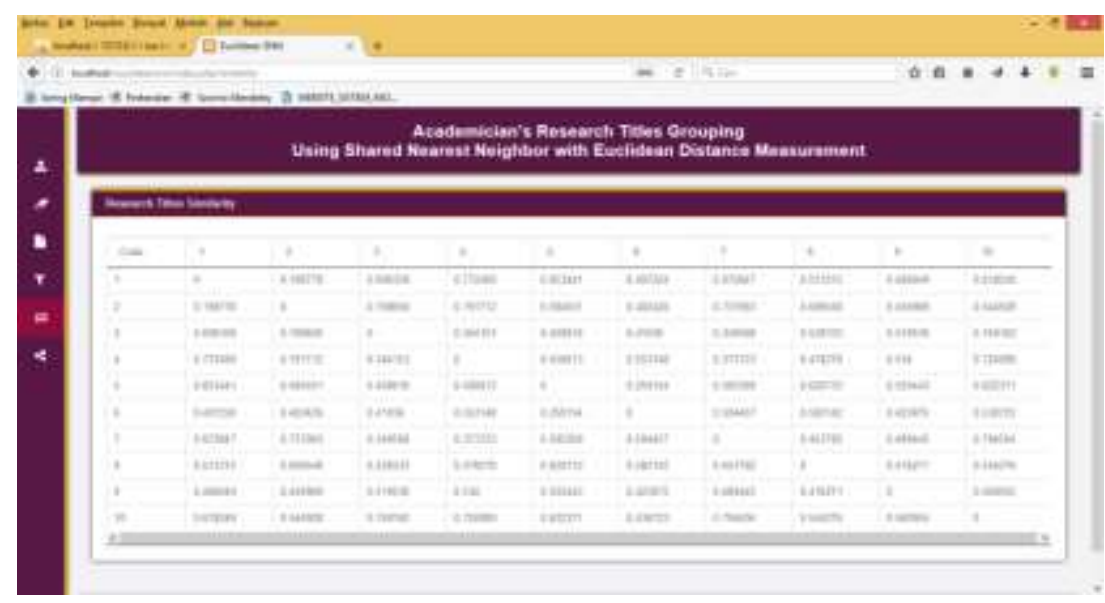

Gambar 9. Tampilan hasil penghitungan similarity 
Jurnal IImu Teknik Elektro Komputer dan Informatika (JITEKI)

Vol. 3, No. 2, Desember 2017

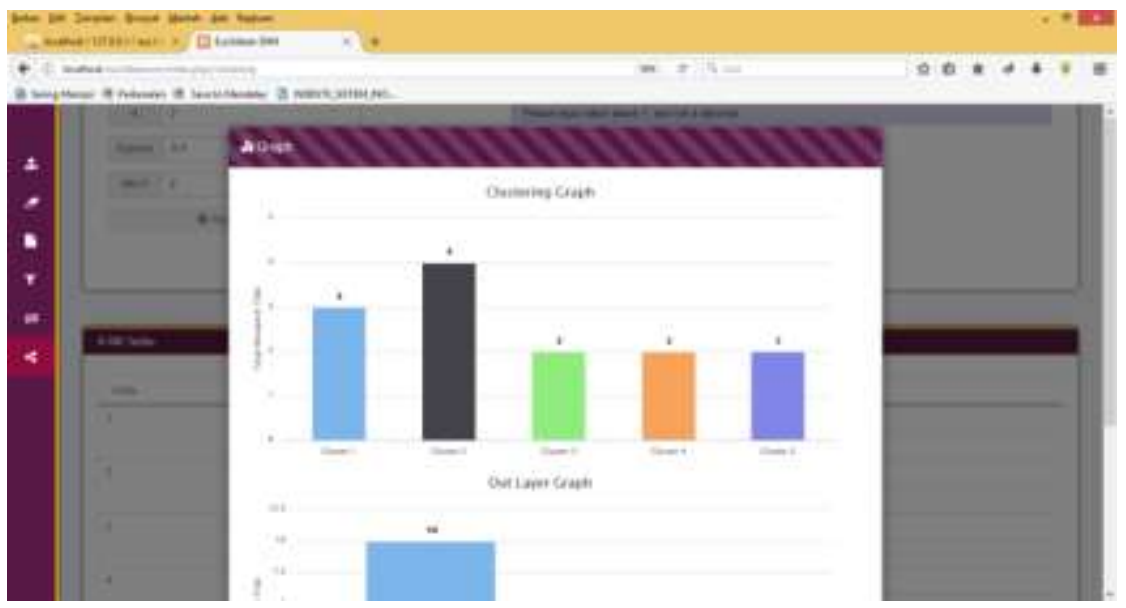

Gambar 10. Tampilan hasil pengelompokkan dalam bentuk grafik

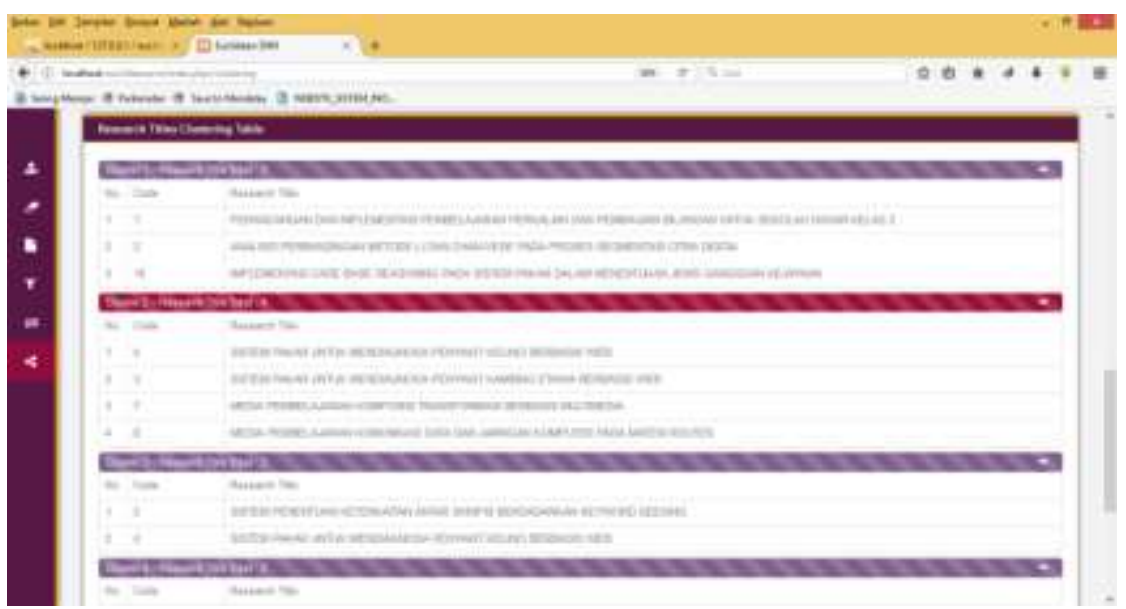

Gambar 11. Tampilan hasil pengelompokkan dalam bentuk list judul

\subsection{Pengujian}

Hasil dari pengujian black box test ini dilakukan terhadap ahli data mining. Dimana hasil dari testing blackbox test.

Tabel 1.Form blackbox test

\begin{tabular}{lllll}
\hline $\begin{array}{l}\text { Test } \\
\text { ID }\end{array}$ & $\begin{array}{l}\text { Function Name / } \\
\text { Process Name }\end{array}$ & Description & Expected Results & $\begin{array}{l}\text { Actual } \\
\text { Results }\end{array}$ \\
\hline 1. & Menu data set & $\begin{array}{l}\text { Klik menu Load } \\
\text { Data }\end{array}$ & $\begin{array}{l}\text { Menampilkan daftar data judul } \\
\text { penelitian dosen }\end{array}$ & $\sqrt{ }$ \\
\hline & $\begin{array}{l}\text { Klik button } \\
\text { Choose File }\end{array}$ & $\begin{array}{l}\text { Menampilkan pop up windows } \\
\text { untuk memilih file yang akan } \\
\text { di upload }\end{array}$ & $\sqrt{ }$ \\
& $\begin{array}{llll}\text { Klik button } \\
\text { Upload }\end{array}$ & & \\
\hline & $\begin{array}{l}\text { Syarat : file yang } \\
\text { di upload } \\
\text { berekstensi .csv }\end{array}$ & $\begin{array}{l}\text { Sistem akan mengunggah file } \\
\text { yang dipilih ke dalam data } \\
\text { base kemudian menampilkan } \\
\text { daftar data judul penelitian } \\
\text { dosen }\end{array}$ & \\
& & & \\
& & \\
\hline
\end{tabular}

Rancang Bangun Aplikasi Text Mining dalam Mengelompokan Judul Penelitian Dosen Menggunakan Metode Shared Nearest Neighbor dan Eucludien Similarity (L. Zahrotun) 
Jurnal IImu Teknik Elektro Komputer dan Informatika (JITEKI)

Vol. 3, No. 2, Desember 2017

\begin{tabular}{|c|c|c|c|c|}
\hline & & $\begin{array}{l}\text { Syarat : File yang } \\
\text { di upload tidak } \\
\text { berekstensi .csv }\end{array}$ & $\begin{array}{l}\text { Menampilkan pesan error, file } \\
\text { yang di upload harus } \\
\text { berekstensi .csv }\end{array}$ & $\sqrt{ }$ \\
\hline 2. & Menu Cleaning & $\begin{array}{l}\text { Klik Menu } \\
\text { Cleaning }\end{array}$ & $\begin{array}{l}\text { Menampilkan daftar data judul } \\
\text { penelitian dosen yang sudah } \\
\text { melalui proses cleaning data } \\
\text { (cleaning: menghapus data } \\
\text { yang kosong) }\end{array}$ & $\sqrt{ }$ \\
\hline 3. & Menu tokenizing & $\begin{array}{l}\text { Klik menu } \\
\text { Selection }\end{array}$ & $\begin{array}{l}\text { Menampilkan daftar data } \\
\text { konsumen hasil seleksi, }\end{array}$ & $\sqrt{ }$ \\
\hline 4. & Menu filtering & $\begin{array}{l}\text { Klik menu } \\
\text { Filtering }\end{array}$ & $\begin{array}{l}\text { Menampilkan daftar kata } \\
\text { Menampilkan daftar hasil } \\
\text { filtering }\end{array}$ & $\sqrt{ }$ \\
\hline 7. & Menu similarity & $\begin{array}{l}\text { Klik menu } \\
\text { similarity }\end{array}$ & $\begin{array}{l}\text { Menampilkan halaman hasil } \\
\text { penghitungan similarity }\end{array}$ & $\sqrt{ }$ \\
\hline \multirow[t]{3}{*}{8.} & Menu Clustering & $\begin{array}{l}\text { Klik menu } \\
\text { clustering }\end{array}$ & $\begin{array}{l}\text { Menampilkan hasil } \\
\text { pengelompokkan judul } \\
\text { penelitian dosen dalam bentuk } \\
\text { data dan grafik }\end{array}$ & $\sqrt{ }$ \\
\hline & & $\begin{array}{l}\text { Syarat : form } \\
\text { input tidak diisi } \\
\text { semua }\end{array}$ & $\begin{array}{l}\text { Muncul peringatan form } \\
\text { validasi yang belum diisi }\end{array}$ & $\sqrt{ }$ \\
\hline & & $\begin{array}{l}\text { Syarat : form } \\
\text { input diisi semua }\end{array}$ & $\begin{array}{l}\text { Menampilkan halaman fold- } \\
\text { growth dengan hasil pola } \\
\text { assosiasi }\end{array}$ & $\sqrt{ }$ \\
\hline
\end{tabular}

Dari hasil penilaian dan pengujian blackbox test, dapat disimpulkan bahwa aplikasi data mining segmentasi konsumen sudah mampu melakukan proses clustering dengan baik dan berfungsi sebagaimana mestinya.

\subsection{Representasi Pengetahuan dan Evaluasi Pola}

Dari hasil pengujian Black box test telah dihasilakan sebuah aplikasi data mining berbasis web yang mampu melakukan pengelompokkan judul penelitian dosen. Dari hasil aplikasi yang ada maka dilakukan analisis terhadap hasil pengelompokkan.

\section{Kesimpulan}

Dari penelitian yang telah dilakukan dapat disimpulkan bahwa aplikasi text mining yang dibangun dapat berjalan dengan baik. Hal ini berdasarkan hasil pengujian dari black box test. Selain menampilkan judul penelitian dosen aplikasi yang dibangun dapat menampilkan proses cleaning, tokenizing, dan filtering dan proses pengelompokkan judul penelitian dosen menggunakan metode SNN dan eucliean similarity.

\section{Ucapan Terima Kasih}

Penelitian ini telah didukung oleh hibah penelitian RISTEK DIKTI dengan skema Penelitian Dosen Pemula (PDP) tahu anggaran 2017

\section{Referensi}

[1] R. Janani and S. Vijayarani, "Text Mining Research: A Survey," Int. J. Innov. Res. Comput. Commun. Eng., vol. 4, no. 4, pp. 6564-6571, 2016.

[2] B. Santosa, Data Mining Teknik Pemanfaatan Data untuk Keperluan Bisnis. Yogyakarta: Graha IImu, 2007.

[3] R. F. Zainal and A. Djunaidy, "Algoritma Shared Nearest Neighbor Berbasis Data Shrinking," JUTI, vol. 7, pp. 1-8, 2008.

[4] L. Zahrotun, "Comparison Jaccard similarity , Cosine Similarity and Combined Both of the Data Clustering With Shared Nearest Neighbor Method," vol. 5, no. 1, pp. 11-18, 2016. 
[5] Mushlihudin and L. Zahrotun, "Perancangan Text mining Pengelompokkan Penelitian Dosen Menggunakan Metode Shared Nearest Neihbor dengan Euclidean Similarity," in Seminar Nasional Teknologi dan Informatika (SNATIF), 2016, pp. 849-855.

[6] S. Jiang, G. Pang, W. Meiling, and K. Limin, "An Improved K-Nearest-Neighbor Algoritm for Text Categorization," Expert Syst. with Appl., vol. 39.1, pp. 1503-1509, 2012.

[7] C. Li and L. Nan, "A Novel Text Clustering Algorithm," Energy Procedia, vol. 13, pp. 35833588, 2011.

[8] R. Handoyo, S. M. Nasution, P. Studi, S. Komputer, S. Linkage, and S. Coefficient, "Perbandingan Metode Clustering Mengggunakan metode Single Linkage dan K-Means Pada Pengelompokkan Dokumen," JSM STMIK Mikroskil, vol. 15, no. 2, pp. 73-82, 2014.

[9] T. Alfina and B. Santosa, "Analisa Perbandingan Metode Hierarchical Clustering, K-Means dan Gabugan Keduanya dalam Membentuk Cluster Data (Studi Kasus: Problem Kerja Praktek Jurusan Teknik Industri ITS)," J. Tek. POMITS, vol. 1, no. 1, pp. 1-5, 2012.

[10] A. K. Patidar, J. Agrawal, and N. Mishra, "Analysis of Different Similarity Measure Functions and their Impacts on Shared Nearest Neighbor Clustering Approach," Int. J. Comput. Appl., vol. 40, no. 16, pp. 1-5, 2012. 